\title{
Understanding the Potential Impact of IFRS 15 on the Telecommunication Listed Companies, by the Disclosures' Study
}

\author{
Giorgia Mattei ${ }^{1} \&$ Niccolò Paoloni ${ }^{2}$ \\ ${ }^{1}$ Business Studies Department, Roma Tre University, Italy \\ ${ }^{2}$ Engineering Department, Roma Tre University, Italy \\ Correspondence: Giorgia Mattei, Department of Business Studies, University of Roma Tre, Rome, Italy. E-mail: \\ giorgia.mattei@uniroma3.it
}

Received: September 27, 2018

Accepted: November 26, 2018

Online Published: December 23, 2018

doi:10.5539/ijbm.v14n1p169

URL: https://doi.org/10.5539/ijbm.v14n1p169

\begin{abstract}
IFRS 15 "revenues from contracts with clients", became mandatory for the IFRS compliance companies as from the 1st January 2018. From different studies, appear that the telecommunications companies represent the major industry impacted from the adoption of the new standard. In the present study were selected the Telecommunications companies listed in the Italian and Spanish market.

The methodology used to carry out this research is the content analysis, using the paradigm of the stakeholder theory.

From the findings of the research, it is possible to hypothesize that exist a direct correlation between the potential impact of IFRS 15 and the quantity and quality of information provided in the annual report elaborated for the two years prior to adopting the new standard.

This result could also be used to understand the listed Telecommunications companies managers' capabilities. In fact, it is renowned that the best managers could be retained to give more importance to stakeholders by supplying more information about the adoption of standard IFRS 15.
\end{abstract}

Keywords: Telecommunications companies; Disclosures; IFRS 15; Stakeholder theory; Revenues.

\section{Introduction}

From 1 January 2018, all IFRSs adopter entities have to start to use a new standard, as IFRS 15, "Revenue from contracts with customers".

This principle is considered as ones of the most important standards elaborated since the accounting rules have been rewritten for recognition and measurement of an item that is present in the financial statement of all company, regardless of the sector in which it operates. Revenues are considered as an ideal component to examine as it is the largest earnings component for most firms (Stubben, 2010).

Moreover, revenues are considered an important measure of an entity's performance because they are used both by investors and from others to make the decision about investments (Tong, 2014).

IFRS 15 was born from a conjunction project between US FASB and IASB. The exigence to have the same criterion to recognize and to measure the revenues appear because, till IFRS 15, FASB and IASB had two different standards and this previous situation could compromise international comparability of financial statements. Considering the exigencies of the investors that want high-quality and comparable financial information, FASB and IASB decided to sign, in 2002, the Norwalk Agreement that proclaimed their intentions to eliminate the differences between US GAAP and IFRSs and to develop one set of high quality global accounting standards, among which, ones with topic on revenue recognition (Khamis, 2016).

With the aims to:

1. solicit, analyze, and discuss stakeholder issues arising from the implementation of the new guidance;

2. inform the FASB and the IASB about those implementation issues, which will help the Boards determine what, if any, action will be needed to address those issue;

3. provide a forum for stakeholders to learn about the new guidance from others involved with 
implementation;

was created a technical working group called TRG - Transition Resource Group (Note 1). This group meets periodically to discuss potential issues arising from the implementation of the new revenue recognition guidance (ASU Topic 606/IFRS 15). It is not up to the TRG to issue guidance, but the FASB, joint with the IASB will determine what action, in any, will be taken on each issue.

The first exposure draft of IFRS 15 (ED/2010/6) was issued in June 2010 and a revised exposure draft (ED/2011/6) was later issued in November 2011 (Steele, 2012, Bohusova and Nerudova, 2009). Finally, in 2014, the final version of the standard that discipline "Revenue from contracts with customers" was published.

As already mentioned, the impact of the adoption of IFRS may have a significant effect on the financial statements of many entities as the amount of revenues and contract costs and/or the timing of their recognition may differ significantly from the current practice, considering also, that this standard require some of the additional disclosures (Note 2).

Considering, therefore, that this standard will provoke strong impacts, knowing that IAS 8 Accounting Policies, changes in accounting estimates and errors required when there is a new standard that has been issued but is not yet effective, as well as what IFRS 15 requires to transit to this new standard, became important to analyze the behavior of the managers' companies IFRSs adopter in the two-year period before the adoption of the new principle.

About this, during 2016, some regulators stressed the importance of entities to provide information in the disclosures about indications and expectations that can get off from the adoption of IFRS 15.

Looking at the indications provided in the Public Statement "Issues for consideration in implementing IFRS 15 Revenue from Contracts with Customers", published in 20 July 2016 from ESMA (Note 3), the present study is aimed to analyze if, in the annual financial report (elaborated for 2016 and 2017), the companies included in the sample, have provided a minimum level of information, if they gave more than required or if they didn't consider these guidelines. So, the research question of the present paper is:

RQ: Exist a direct correlation between the potential impact of IFRS 15 and the quantity and quality information provided in the annual reports elaborated for the two years before the adoption of a new standard?

From the answer of this question, it is possible to hypothesize that exist (or not) a direct (or indirect) correlation between the potential impact of IFRS 15 and the quantity and quality of information provided in the annual report elaborated for the two years prior to adopting the new standard.

To do this analysis it was decided to only consider the listed Italian and Spanish Telecommunications companies, because, as already asserted by the "Big-Four", the entities considered part of this industry will be greatly impacted by the implementation of the new principles than others, so it can be assumed that these companies have to provide more attention than others as regards this topic.

The content analysis methodology has been used to carry out this research.

Thanks to the findings arose from this analysis it is possible to see that Telecommunications companies are sensitive to the issue of the introduction of the new IFRS 15 as they will undergo a major change in the adoption of the new accounting principle, so it is possible to hypothesize that exist a direct correlation between the potential impact of IFRS 15 and the quantity and quality of information provided in the annual report elaborated for the two years prior to adopting the new standard. This also allows drawing first conclusions about the manager's ability to manage the relationship between the company and the stakeholders.

Henceforth, the paper is organized as follows:

Section 2 discusses the concepts of provisions contained in IFRS 15 regarding the disclosures and the relations with a theoretical framework as the stakeholder theory. Section 3 briefly explains the methodological issues. Section 4 presents the evidences derived from the content analysis. Section 5 concludes with final reflections and lesson learned.

\section{Background}

\subsection{Literature background about stakeholder theory and their relation with disclosures}

A company's success is determined by its ability to establish and maintain relationships with its stakeholders (Post et al., 2002); therefore, the success of companies requires the support of all its stakeholders. Gaining this support and approval requires a dialogue between the management of a corporation and its stakeholders (Van der Laan Smith et al., 2005). 
With this in mind, it is clear how the stakeholder theory can be used to analyze the situation of companies. In fact, the literature provides the possibility to assert what exists to the needs to manage stakeholder groups; some scholars (see, i.e., Chiu \& Wang, 2015) assert that a principal function of the manager is to handle stakeholders' needs, expectations, and demands to balance conflicts among them. A particular focus is directed towards those stakeholders capable of controlling resources required by a company (Oliveira et al., 2013).

Considering from the accounting perspective, the main method the company could use to communicate with the stakeholders is through annual reports, these include the financial statements and others information that are provided in the disclosure. This document is prepared to get clear the policy adopted by companies to stakeholders and to provide the basis for their decision-making (Stolowy \& Lebas, 2004; Foster, 1986). Moreover, corporate disclosure helps negotiate the relationship between a company and its stakeholders (Gray et al., 1995). To consider the disclosure as useful, they must be: i) understandable, ii) relevant, iii) reliable, iv) comparable, and v) timely (IASC, 1989).

Write up disclosures is a demanding job because these have a complex function determinate by both internal and external factors (Lopes \& Rodrigues, 2007), also called "contingency factors" (Burns \& Stalker, 1961). Following the Lopes \& Rodrigues (2007) ideas, it is possible to considered the "internal factors" as all factors which depends on the company and, in the other hand, the "external factors" which are related to the environmental context of the company, such as culture, legal system, institutional background. Disclosure could be considered as a tool to facilitate credible disclosures between managers and investors (Healy \& Palepu, 2001).

Disclosures are regulated in all countries around the world. Beside the "regulated" or "mandatory" disclosures, there is another type called "voluntary" disclosure. Some scholars (see i.e., Cooke, 1992) consider this distinction subjective for different reasons, as: i) not all companies comply with mandated disclosures; ii) the distinction between mandatory and voluntary disclosures is often blurred.

In fact, this situation is observable also about the instructions provided regarding IFRS 15.

In this new standard are required a lot of (mandatory) disclosures, always respecting the adoption form of the principle. As regards the previous period (2016 and 2017), it is important to refer to IAS 8 "Accounting Policies, Changes in Accounting Estimates and Errors". This last standard requires disclosure of an impending change in accounting policies when a new IFRS has been issued but not yet into force.

Considering that a standard that regulates the recognition of "revenue from contracts with clients" will have an important impact, the European Securities and Markets Authority (ESMA), with the objective of assessing the level of transparency and effectiveness of disclosure on the impact of the implementation of the new standards (ESMA: 2017), issued a Public Statement on the implementation of IFRS 15 as required to list companies that have to use it as from January 2018, to provide information in the disclosure, about the potential impact of new standard. The following sub-paragraph has summarized the content of the new standard.

\subsection{Summary of IFRS 15}

The new standard is designed to improve the financial reporting of revenue globally, which previously often resulted in different financial accounting for economically similar revenue transactions under IFRS and GAAP (Bloom \& Kamm, 2014).

The aim of the IFRS 15 is to establish the principles that an entity shall apply to report useful information to users of financial statements about the nature, amount, timing and uncertainty of revenue and cash flows arising from contracts with a customer (IFRS 15:1).

To achieve the objective, an entity has to recognize the revenues from the contracts with clients to depict the transfer of promised goods or services to customers at an amount that reflects the expectation of the entity in exchange for those goods or services (IFRS 15:2).

By introducing the IFRS 15, the determination of revenue requires an estimation procedure, which in turn requires an evaluation of different components that may not always be simple and measurable to identify (Holzmann \& Munter, 2015; Bianchi \& Ballarin, 2016). When applying this new standard, an entity shall consider the terms of the contract all relevant facts and circumstances. It is possible to apply the IFRS 15 considering similar characteristics and in similar circumstances (IFRS 15:3). The focus is too different contracts with similar features: the entity may, therefore, treat the portfolio as a single contract provided that the effects deriving from this choice do not differ substantially from the effects that would arise in case of separate treatment of the contracts in the portfolio.

The IFRS 15 came into force on the $1^{\text {st }}$ of January 2018 and replaced the IAS 11 - Customs works; IAS 18 - 
Revenues; IFRIC 13 - Customer loyalty programs; IFRIC 15 - Agreements for the construction of buildings; IFRIC 18 - Sales of business by customers; SIC 31 - Revenues - Barter transactions including advertising services. Those contracts whose accounting treatment is governed by other standards are excluded. One of the most innovation of this standard is the "five" steps method, by which is request to: i)identify the contract with the customer; ii)identify the performance obligations in the contract; iii)determine the transaction price; iv)allocate the transaction price to the performance obligations; v)recognize revenue when (or as) the entity satisfies a performance obligation (Munter, 2016).

This IFRS 15 applies contract-based revenue reporting as contrast to other IFRSs, such as IAS 41 Agriculture which is an activity-based income reporting.

Another essential feature of this new IFRS is the concept of "performance obligation (Note 4)" embodied in a contract with a customer to provide goods and services in exchange for consideration (Lim et al., 2015).

The nature, timing and amount of consideration promised by a customer affect the estimate of the transaction price.

\section{Methodology}

The stakeholders' theory (Freeman, 2010) asserts that managers must formulate and implement processes, which satisfy the interests of all those who provide contributions to the company or that are influenced by its decisions.

The managers shall give the aim to maintain a balance between all stakeholders' categories interests and their expectations that converge to the company. Freeman (1984) suggests that to realized efficiently this objective, they have to manage the relations between company and stakeholders, whilst considering three different levels:

- "rational" level of analysis. At this level, strategic managers must "map" their organizational stakeholder groups and accurately define the interests each has in its operations;

- "process" level. Strategic managers must include stakeholders in the firm's actual strategic decision-making process with the view to use their multiple perspectives as a resource for the organization;

- "transaction" level of analysis. Strategic managers must establish and execute "win-win" transactional exchanges with their stakeholders.

The capability of the managers to efficient and coherent realize these three levels of analysis could be defined as the capabilities to manage the expectations of the stakeholders.

It is not easy task to attribute the different groups of stakeholders at macro categories but, as asserted by Fassin (2009), after an analysis of the literature referring to the stakeholders' selection, the scholars have unanimously identified the three major stakeholder groups: financiers, employees, and customers.

Limited the present analysis to one group of stakeholder, as the financiers, a sample of the Italian and Spanish companies were selected. The choice to consider Italian companies was made because, in Italy, frequently, the companies are family owned and are primarily financed by banks; consequently, creditors are considered to be the main recipients and users of corporate financial statements and they have direct access to detailed performance information (Fox et al., 2013).

Downside, considering the listed companies, where the market has no possibility to direct access of all the information, it evidently shows an important need to focus on the detailed financial statements (Viganò, 1990). The similar situation finding in Italy could be observed in Spain. In fact, it is renown that Italy and Spain are considered from the corporate governance scholars, belonging at the same set called "insider system" where the owners of firms tend to have an enduring interest in the company and often hold positions on the board of directors or other senior managerial positions (Eurofound, 2002; Barker, 2006), as well as the relationships with banks, are strong, and large family holdings often dominate institutional investors (Maher \& Andersson, 2002).

Therefore, companies belonging to the telecommunications sector were chosen amongst the Italian and Spanish listed companies were selected.

Between all industries, the choice to analyze the telecommunications companies arose from the considerations done by the Big-Four; in fact, these, in the study carried out in relation to the forecast of the impact that IFRS 15 will have in the various sectors, are unanimous in considering that telecommunications will be subject to greater changes than the others (Note 5).

Using the stakeholder theory framework, applying to this a content analysis, it is possible to observe if the Telecommunications listed-companies managers well manage the relationships between the company and financiers that are, as it is asserted from scholars, one of the groups that determine the company's successful 
(Oliveira et. al, 2013).

The methodology used for this work is a content analysis, defined by some scholars (i.e. Krippendorff, 1983:37) as «[...] a research technique for making replicable and valid inference from texts to the context in which they are used». Other scholars (see, i.e. Berelson, 1952) describes content analysis as a research technique used to provide a systematic and quantitative objective description of the content of a communication. Following both definitions, a content analysis approach has been used in the present work by authors to analyze if the level of the information provided from Telecommunications Italian and Spanish listed-companies managers' is in line with the request elaborated both by IFRS 15 and by ESMA in 2016.

Both in the Italian stock exchange and in the Spanish one, there are 7 companies that belong to the telecommunications industries, creating a sample of 14 companies. Analysing that sample, it is possible to observe that one company is quoted in both markets (Telefonica S.A.). Considering that for answering at the research question is important to understand if the companies provided information about IFRS 15 before then the mandatory adoption of it and not analyze the differences between the listed companies in 2 different markets, it was decided to consider Telefonica S.A. only once time, in detail, only in the Italian sub-sample. At this point it is possible to assert that the sample is composed by 13 companies.

For each of these, it was analyzed the disclosure contained in the annual reports elaborated for the years 2016 and 2017 and each annual report was found on the website of the company. The total observations are 26.

As it is suggested from the literature (Carney, 1971; Lindenmann, 1983), after having made this first step concerning the choice of the sample and the type of document to be analyzed, it is necessary to move on to the second phase concerning the choice of the measuring unit to determine the space occupied in the document by each informative category. About this, in the present work, it was decided to use "word" as the measuring unit.

The third step concern the choice of the informative categories within which to trace the information sought in the text. To helps the authors to identify the informative categories, it was used the considerations raised from ESMA publication. In fact, after identifying the information category, which is "Information about IFRS 15", were identified the information sub-categories, determined in relation to the different years analyzed (2016 and 2017). That is:

- companies provided relevant and specific information in relation to the project for the implementation of IFRS 15 in 2016;

- companies have progressively provided more relevant and specific information as the IFRS 15 implementation project progresses (2017).

Considering that the information contained in the disclosure is a complex multi-faceted concept (Beattie et al., 2004), the information was analyzed in two different dimensions that are (Teodori \& Veneziani, 2013): i) expression methods; ii) time.

Regarding the first point (expression methods) it was decided to distinguish the information between qualitative or narrative and quantitative.

Regarding the second point (nature of information) it was decided to identify the information that discusses the actual situation differentiating that by others that trait the possible future impact for the companies.

In the following paragraph, the findings generated by the analysis carried out in the telecommunications industry are shown.

\section{Results}

With the content analysis, it is possible to find that $69,23 \%$ of the Telecommunications sample discussed IFRS 15 in 2016, while the percentage grow up in 2017 at $84,62 \%$. This means that while 2016, are 4 the companies did not provide information about the application of IFRS 15 (Cellnex Telecom. S.A; Global Dominion Access. S.A.; Grupo Ezentis. S.A. and Vetrya SpA) of which 3 belonging to Spanish market while 1 belonging to the Italian market, in 2017 are only two the companies (Vetrya SpA and Global Dominion Access. S.A.) out of 13 that not dealing with it, one Spanish and one Italian. This shows that following the mandatory adoption of the new accounting standard, companies attribute more importance to the information to be provided in the disclosures. All the companies debating about this new standard (Deutsche Telekom AG; Orange SA; Retelit $\mathrm{SpA}$; Telecom Italia SpA; Telefonica SA; Tiscali SpA; America Movil S.A.B.; Euskal Tel S.A.; Masmovil Ibercom. S.A) talked about it only in terms of quality in 2016; in 2017, 6 out of 11 (Deutsche Telekom AG, Orange SA, Retelit SpA, Telefonica SA; America Movil S.A.B.; Euskal Tel S.A.; Masmovil Ibercom S.A.) also provided information about the quantitative aspect. Even if $53,85 \%$ of the companies belonging to the sample 
provided, in 2017, to give quantitative information, the number of words reserved for this last aspect is still not relevant. In fact, out of a total of words dedicated to IFRS 15 used by the companies of the sample equal to 6.530 , only $10,98 \%$ (i.e. 717 words) explain in quantitative terms the adoption of the new principle, while the remaining $89,02 \%$ of the words used (i.e. 5.813 words) narratively discuss this issue. It is important to highlight that, on the total 717 words used to discuss IFRS 15 in quantitative terms, 396 (47,31\%) have been used by a single company, which is the Deutsche Telekom AG.

To confirm that the attention to the impact of the new standard grows up gradually considering the imminence of the mandatory adoption, another element has been analyzed; in fact, it was observed if the companies provided the greater relevance and greater detail of the information provided. Regarding this, all companies that are inside the sample have provided more and greater detail information in 2017 than in 2016. In fact, while in 2016 the companies used, in total, 2.536 words to speak about IFRS 15, in 2017 the words used were 6.530, this show an increase in the number of words used (in detail are used 3.994 words more), therefore, the increase is equal to $157,50 \%$. Deutsche Telekom AG, is the company that has significantly increased the number of words dedicated to IFRS 15 compared to the others, going from 498 in 2016 to 1.965 in 2017, with a delta of $1.467(+294,60 \%)$ words more in the second year analyzed.

The others companies that belong to the sample, although recording lower percentages compared to the one above, had nevertheless significantly increased the space dedicated to the new accounting standard; the percentages of increase, in fact, went from $+293,90 \%$ of Euskal Tel S.A., up to $+262,60 \%$ of Masmovil Ibercom S.A., to $+114 \%$ of America Movil S.A.B.. The others companies have increased the number of words used in the two years of observation, respectively for: Retelit $\mathrm{SpA}+94,70 \%$; Telecom Italia $\mathrm{SpA}+85,30 \%$; Tiscali $\mathrm{SpA}$ $+63,40 \%$; Orange S.A. $+53,00 \%$ and, finally, Telefonica S.A. $+11,70 \%$. Cellex Telecom S.A. and Grupo Ezentis S.A. that have not to provide information 2016, dedicated respectively 5 words and 159 words in 2017 to discuss IFRS 15 .

Furthermore, in 2016 all companies spoke about the new principle in a paragraph of the disclosure, in 2017 Deutsche Telekom AG deals with this topic in two paragraphs.

Considering that the analysis done till now could contain general information about the function of IFRS 15 and specific information regarding the potential impact of this principle on the financial statement of each company, it was decided to continue the research looking at the last item explained. Specifically, it was analyzed the disclosure focusing on the section which talks about the future impact of IFRS 15 that could differ from one company to the other, also if all belong to the same industry, such as Telecommunications. The result arises from this activity, carried out using the annual reports elaborated for the year 2017, shows that 10 on 13 companies gave information about the future predictable impact of IFRS 15 on its financial statement. As the previous results, Deutsche Telekom AG is the company that gave more emphasis on this item, using 1.217 words. On the other side, Tiscali SpA, Orange SA, Grupo Ezentis. S.A. and Telefonica SA although have talked about it, dedicated some spaces to it because they used less than 60 words (specifically, Orange SA 58 words, Tiscali SpA 35, Grupo Ezentis S.A. 27 and Telefonica S.A. 30). Then, there are 5 companies that gave an average informative, using a number of words included between 121 and 583 (America Movil S.A.B. 583 words; Retelit SpA 317 words; Telecom Italia SpA 212 words; Euskal Tel S.A. 187 and Masmovil Ibercom S.A. 121).

\section{Discussion and Conclusions}

After the study carried out it is possible to conclude that the Italian and Spanish listed companies belonging to the Telecommunications sector, in general, have shown attention to the new accounting standard IFRS 15 which is obligatorily adopted by the IFRS' compliant companies as from the 1 of January 2018 . These results give the possibility to authors to answer at the RQ of the present work that is:

RQ: Exist a direct correlation between the potential impact of IFRS 15 and the quantity and quality information provided in the annual reports elaborated for the two years before the adoption of a new standard?

In fact, generally, Telecommunications industry companies, that will be one of the industries to be impacted more than other from the IFRS 15 adoption, considering the specific of the typology of contracts stipulated in this sector, provide an adequate level of information about the new standard.

Analyzing the annual reports of the years 2017 publicly available, it is noted that, with the exception of two out of thirteen companies in the sample, all provide information on the new accounting standard (while was four out of thirteen 2016).

Taking, again, the recommendations provided by ESMA, it was also noted that with the approach of the new principle coming into force, companies have given greater importance and provided a greater detail to the 
information on the new standard.

The information that can be found in the documents is, in all the cases analyzed, more detailed from a qualitative point of view with respect to the quantitative aspect.

Considering that the sample is composed by companies listed in two different markets, the analysis could also expand take into account the possibility that the companies quoted in Italian market are more sensitive to the "new" recognize rules for revenues than the others quoted in the Spanish market or conversely.

Looking at the findings obtained by the content analysis it is possible to observe that the Italian companies start to explain the foreseeable impact of IFRS 15 in advance compared to the Spanish companies and, furthermore, also if the Spanish companies have given a space at this topic, compared with the action done by the Italian Telecommunications companies it is possible to assert that the former paid less qualitative and quantitative attention to this topic.

Besides, the analysis shows that no Italian and Spanish listed companies belonging to the indigent sector have tried to voluntarily apply the accounting principle in advance of the mandatory adoption date; conversely, companies that had done so could also quantify the impact that IFRS 15 has on the financial statements of individual companies. But, at the same time, demonstrate that in these companies there are managers that are able to balance stakeholders' interests and their expectations that converge to the company. The ability of these managers is deductible from the fact that disclosures report information about IFRS 15.

Considered that the disclosures are a tool to facilitate relations between stakeholders and company, more information and higher quality information contained in the annual reports could be considered as a better management relationship.

This is a preliminary study and has some limits. For example, the intention of the authors is to do the same analyses considering others industries to verify if the relation between industry and level of information provided about the adoption of IFRS 15 exist. If this could be verifiable, it will be also possible to assert that there will be some industries where the new accounting principle will influence more than others. This assertion is also supported by the attention that managers give to the information that provisions regarding the new accounting treatment of revenues from contracts with clients.

In future years the authors' project is to test the results obtained in the present work using data that will be ready not before the approval of annual report 2017; however, to verify if Telecommunications companies will be more impact than other from the adoption of IFRS 15 it will be necessary to select companies that belonging to other industries.

\section{References}

Ballarin, F. (2017). IFRS 15: implicazioni per gli operatori nelle telecomunicazioni. Amministrazione \& Finanza, 17, 7-11.

Barker, R. M. (2006). Insiders, outsiders, and change in European corporate governance. In Council for European Studies Conference, Chicago, IL(Vol. 31).

Beattie, V., McInnes, B., \& Fearnley, S. (2004). A methodology for analysing and evaluating narratives in annual reports: a comprehensive descriptive profile and metrics for disclosure quality attributes. Accounting Forum, 28(3), 205-236). Elsevier.

Berelson, B. (1952). Content Analysis in Communications Research. New York: Hafner.

Bianchi, S., \& Ballarin, F. (2016). IFRS 15: la transizione al nuovo standard. Amministrazione \& Finanza, 8(9), 17-23.

Bloom, R., \& Kamm, J. (2014). Revenue recognition: how we got here and where it will take us. Financial Executive, 30(3), 48-53.

Bohusova, H., \& Nerudova, D. (2009). Us Gaap and Ifrs Convergence In The Area Of Revenue. Economics \& Management, 12-19.

Burns, T. E., \& Stalker, G. M. (1961). The management of innovation. Tavistock, London

Carney, T. F. (1971). Content analysis: A review essay. Historical Methods Newsletter, 4(2), 52-61.

Chiu, T. K., \& Wang, Y. H. (2015). Determinants of social disclosure quality in Taiwan: An application of stakeholder theory. Journal of Business Ethics, 129(2), 379-398. https://doi.org/10.1007/s10551-014-2160-5 
Cooke, T. E. (1992). The impact of size, stock market listing and industry type on disclosure in the annual reports of Japanese listed corporations. Accounting and Business Research, 22(87), 229-237. https://doi.org/10.1080/00014788.1992.9729440

ESMA. (2017). Report, Enforcement and Regulatory Activities of Accounting Enforcers in 2017.

Eurofound. (2002). Corporate governance systems and the nature of industrial restructuring. Retrieved November

2018 , https://www.eurofound.europa.eu/publications/report/2002/corporate-governance-systems-and-the-nature-of -industrial-restructuring

Fassin, Y. (2009). The stakeholder model refined. Journal of business ethics, 84(1), 113-135. https://doi.org/10.1007/s10551-008-9677-4

Foster, G. (1986). Financial statement analysis (2nd ed.). Englewood Cliffs, New Jersey: Prentice-Hall, Inc.

Fox, A., Hannah, G., Helliar, C., \& Veneziani, M. (2013). The costs and benefits of IFRS implementation in the UK and Italy. Journal of Applied Accounting Research, 14(1), 86-101. https://doi.org/10.1108/09675421311282568

Freeman, R. E. (1984). Strategic management: A stakeholder perspective. Boston: Pitman.

Freeman, R. E. (2010). Strategic management: A stakeholder approach. Cambridge University Press.

Gray, R., Kouhy, R., \& Lavers, S. (1995). Corporate social and environmental reporting: a review of the literature and a longitudinal study of UK disclosure. Accounting, Auditing \& Accountability Journal, 8(2), 47-77. https://doi.org/10.1108/09513579510146996

Healy, P. M., \& Palepu, K. G. (2001). Information asymmetry, corporate disclosure, and the capital markets: A review of the empirical disclosure literature. Journal of accounting and economics, 31(1-3), 405-440. https://doi.org/10.1016/S0165-4101(01)00018-0

Holzmann, O. J., \& Munter, P. (2015). Challenges in Achieving Convergence Between US GAAP and IFRS - The Case of the Revenue Recognition Standard. Journal of Corporate Accounting \& Finance, 26(6), 101-106. https://doi.org/10.1002/jcaf.22087

IASC International Accounting Standards Committee. (1989). Framework for the Preparation and Presentation of Financial Statements. London, UK.

Khamis, A. M. (2016). Perception of Preparers and Auditors on New Revenue Recognition Standard (IFRS 15): Evidence from Egypt. Journal Dinamika Akuntansi dan Bisnis, 3(2), 1-18. https://doi.org/10.24815/jdab.v3i2.5383

Krippendorff, K. (1983). Analisi del contenuto: Introduzione metodologica. ERI.

Lim, Y., Devi, S. S., \& Mahzan, N. (2015). Perception of Auditors and Preparers on IFRS 15: Evidence from Malaysia. Advanced Science Letters, 21(6), 1781-1785.

Lindenmann, W. K. (1983). Content analysis: A resurgent communication research technique that represents a wave of the future: The move toward a second dimension of interpretation and analysis. Public Relations Journal, 24-27.

Lopes, P. T., \& Rodrigues, L. L. (2007). Accounting for financial instruments: An analysis of the determinants of disclosure in the Portuguese stock exchange. The International Journal of Accounting, 42(1), 25-56. https://doi.org/10.1016/j.intacc.2006.12.002

Maher, M., \& Andersson, T. (2002). Corporate governance: effects on firm performance and economic growth. Convergence and Diversity in Corporate Governance Regimes and Capital Markets. Oxford University Press, Oxford. https://dx.doi.org/10.2139/ssrn.218490

Munter P. (2016). The New Revenue Recognition Standard: Implications for Healthcare Companies. Management Accounting, 17(2), 30.

Oliveira, L., Rodrigues, L. L., \& Craig, R. (2013). Stakeholder Theory and the Voluntary Disclosure of Intellectual Capital Information. Caspian Journal of Applied Sciences Research, 2(3), 75-93.

Post, J. E., Preston, L. E., \& Sachs, S. (2002). Managing the extended enterprise: The new stakeholder view. California Management Review, 45(1), 6-28. https://doi.org/10.2307\%2F41166151

Steele, C. A. (2012). The Convergence of Us Gaap and Ifrs: Revenue Recognition. Honors Theses, 1-87. 
Stolowy, H., \& Lebas, M. J. (2004). Financial accounting and reporting: A global perspective. London: Thomson Learning.

Stubben, S. R. (2010). Discretionary revenues as a measure of earnings management. The Accounting Review, 85(2), 695-717. https://dx.doi.org/10.2139/ssrn.1135811

Teodori, C., \& Veneziani, M. (2013). L'evoluzione della disclosure nella sezione narrativa: l'impatto dei principi contabili internazionali e del processo di armonizzazione, Giappichelli, Torino.

Tong, T. L. (2014). A Review of IFRS 15 Revenue from Contracts with Customers.

Van der Laan Smith, J., Adhikari, A., \& Tondkar, R. H. (2005). Exploring differences in social disclosures internationally: A stakeholder perspective. Journal of Accounting and Public Policy, 24(2), 123-151. https://doi.org/10.1016/j.jaccpubpol.2004.12.007

Viganò, E. (1990). L’impresa e il bilancio europeo. Saggi di ragioneria internazionale, Cedam, Padova.

\section{Notes}

Note

https://www.fasb.org/cs/ContentServer?c=Page\&cid=1176164066191\&d=\&pagename=FASB $\% 2$ FPage $\% 2 F S e c t i$ onPage

Note

http://www.ey.com/Publication/vwLUAssets/IFRS_Developments,_Issue_126:_Are_you_ready_to_quantify_the _effect_of_adopting_IFRS_15/\$File/Devel126-Revrec-disclosure-survey-May2017.pdf

Note 3. European Securities and Markets Authority

Note 4. A performance obligation is defined as "a promise in a contract with a customer to transfer a good or service to the customer".

Note 5 .

a) KPMG (2016, May), “Revenue - Issues in depth”, available at www.kpmg.com.

b) Ernst \& Young (2016, April), "Revenue from contracts with customers, A summary of IFRS 15 and its effects", available at www.ey.com.

c) In this case, the papers of each sector were analyzed and the relative judgment was taken from the analysis of each. The key element to arrive at the aforesaid judgment was the level of risk of error associated with the steps of the IFRS 15 model.

PriceWaterhouseCoopers (2014, June), “IFRS 15: implementation challenges”, available at from http://www.pwc.com 


\section{Appendix 1: Tables of content analysis}

Table n.1: Sample and analysis concerning the information about IFRS 15

\begin{tabular}{|l|c|c|}
\hline \multirow{2}{*}{$\begin{array}{c}\text { NAME OF ITALIAN } \\
\text { TELECOMMUNCATIONS } \\
\text { COMPANIIS }\end{array}$} & \multicolumn{2}{c|}{$\begin{array}{c}\text { THEY PROVIDE } \\
\text { NFORMATION ABOUT } \\
\text { IFRS 15? }\end{array}$} \\
\cline { 2 - 3 } & $\mathbf{2 0 1 6}$ & $\mathbf{2 0 1 7}$ \\
\hline Deutsche Telekom AG & yes & yes \\
\hline Orange SA & yes & yes \\
\hline Retelit SpA & yes & yes \\
\hline Telecom Italia SpA & yes & yes \\
\hline Telefonica SA & yes & yes \\
\hline Tiscali SpA & yes & yes \\
\hline Vetrya SpA & no & no \\
\hline $\begin{array}{c}\text { PERCENTAGE ONTHE TOTAL } \\
\text { IrALLAN SAMPLE }\end{array}$ & $\mathbf{8 5 , 7 1 \%}$ & $\mathbf{8 5 , 7 1} \%$ \\
\hline
\end{tabular}

\begin{tabular}{|c|c|c|}
\hline \multirow{2}{*}{$\begin{array}{l}\text { NAME OF SPANISH } \\
\text { TELECOMMUNICATIONS } \\
\text { COMPANIES }\end{array}$} & \multicolumn{2}{|c|}{$\begin{array}{c}\text { THEY PROVIDE } \\
\text { INFORMATION ABOUT } \\
\text { IFRS 15? }\end{array}$} \\
\hline & 2016 & 2017 \\
\hline America Movil S.A.B. & yes & yes \\
\hline Cellnex Telecom S.A & no & yes \\
\hline Euskal Tel S.A. & yes & yes \\
\hline Global Dominion Access S.A. & no & no \\
\hline Grupo Ezentis S.A. & no & yes \\
\hline Masmovil Ibercom S.A. & yes & yes \\
\hline $\begin{array}{c}\text { PERCENTAGE ONTHE TOTAL } \\
\text { SPANISH SAMPLE }\end{array}$ & $50,00 \%$ & $83,33 \%$ \\
\hline $\begin{array}{l}\text { PERCENTAGE ON THIE } \\
\text { TOTAL SAMPLE }\end{array}$ & $69,23 \%$ & $84,62 \%$ \\
\hline
\end{tabular}

Table n.2a. Italian and Spanish Telecommunications listed companies and related findings

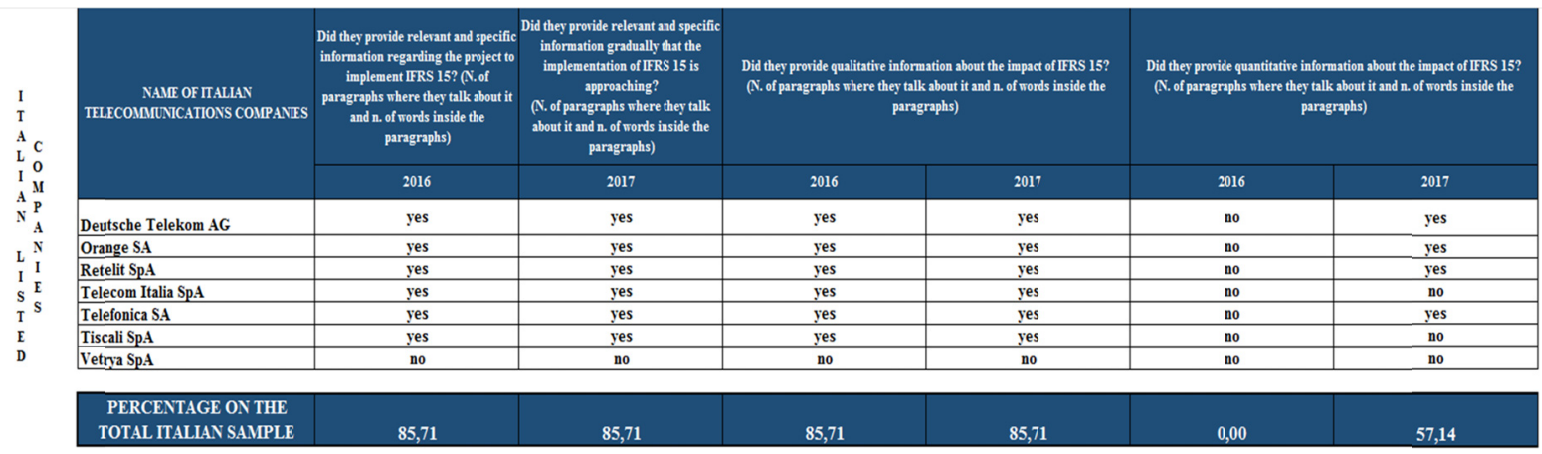

\begin{tabular}{|c|c|c|c|c|c|c|}
\hline \multirow{2}{*}{ 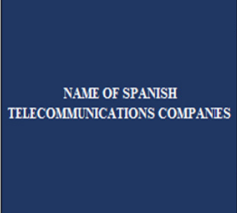 } & \multirow{2}{*}{ 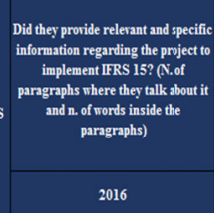 } & \multirow{2}{*}{ 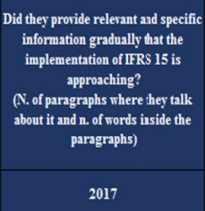 } & \multicolumn{2}{|c|}{ 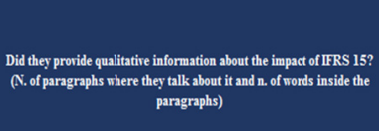 } & \multicolumn{2}{|c|}{ 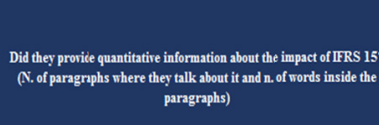 } \\
\hline & & & 2016 & 2017 & 2016 & 2017 \\
\hline America Movil. S.A.B. & yes & yes & yes & yes & no & yes \\
\hline Cellnex Telecom. S.A & no & yes & no & yes & no & no \\
\hline Euskal Tel. S.A. & yes & yes & yes & yes & no & yes \\
\hline Global Dominion Access. S.A. & no & no & no & no & no & no \\
\hline Grupo Ezentis. S.A. & $\begin{array}{ll}\frac{n}{n} \\
\text { ves }\end{array}$ & $\begin{array}{l}\text { yes } \\
\text { yes }\end{array}$ & no & yes & $\frac{\mathrm{no}}{\mathrm{no}}$ & no \\
\hline Masmovil lbercom. S.A. & yes & yes & yes & yes & no & yes \\
\hline $\begin{array}{c}\text { PERCENTAGE ON THE } \\
\text { TOTAL SPANSH SAMPLL } \\
\end{array}$ & 50,00 & 83,33 & 50,00 & 83,33 & 0,00 & 50,00 \\
\hline \begin{tabular}{|l|} 
PERCINIAGE ON THE TOTIL \\
SAMPLE
\end{tabular} & 69,23 & 84,62 & 69,23 & 84,02 & 0,00 & 53,85 \\
\hline
\end{tabular}


Table n.2b. Italian and Spanish Telecommunications listed companies and related numeric findings
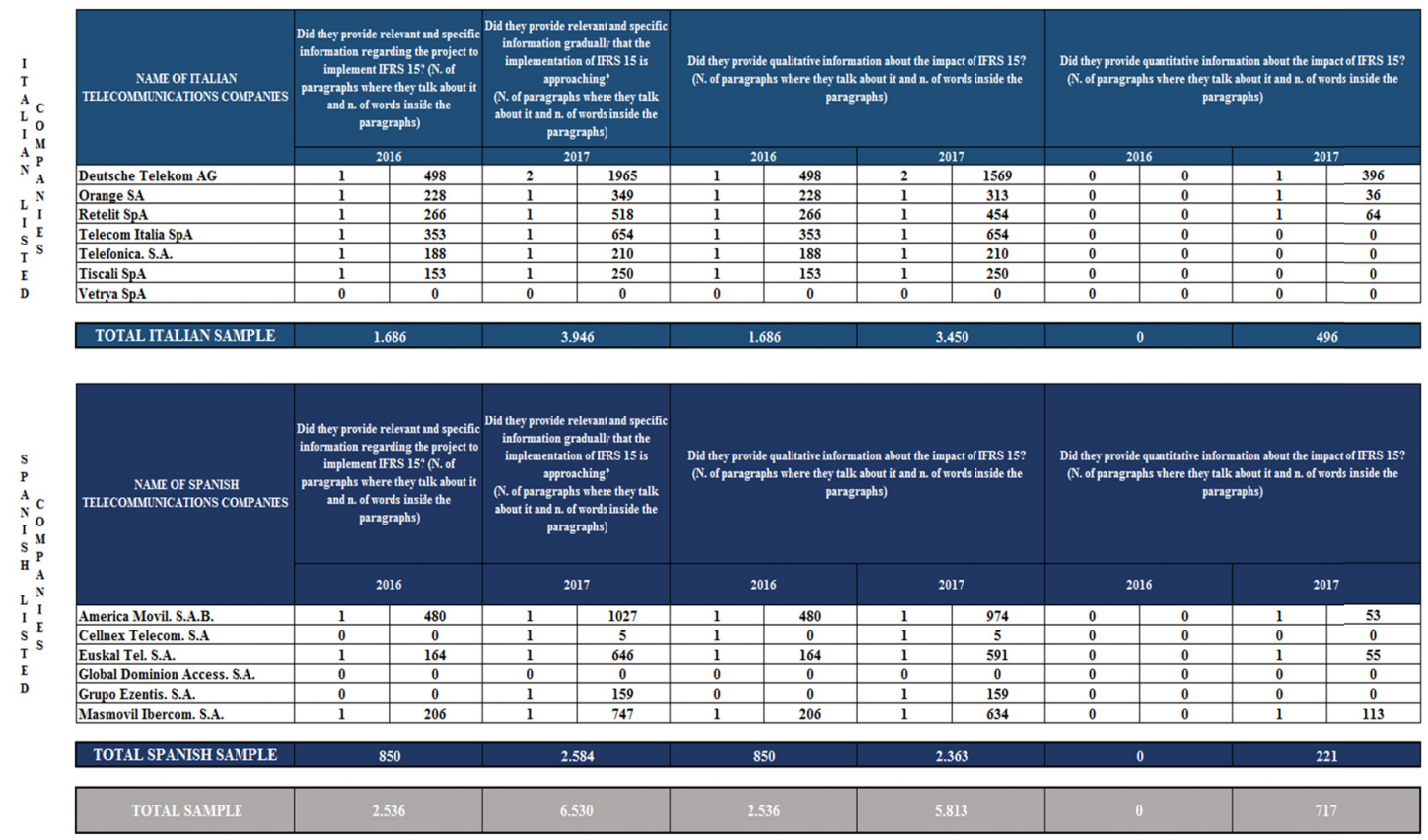

Table n.4. Italian and Spanish Telecommunications listed companies and the information provided about the future impact of IFRS 15

\begin{tabular}{|c|c|c|}
\hline \multirow{2}{*}{$\begin{array}{l}\text { NAME OF ITALIAN TELECOMMUNICATIONS } \\
\text { COMPANIES }\end{array}$} & \multicolumn{2}{|c|}{$\begin{array}{l}\text { The number of words dedicate to the futur impact of IFRS } 15 \text { in each } \\
\text { paragraph that discuss about it }\end{array}$} \\
\hline & N. of words & N. of paragraphs \\
\hline Deutsche Telekom AG & 1.217 & 1 \\
\hline Orange SA & 58 & 1 \\
\hline Retelit SpA & 317 & 1 \\
\hline Telecom Italia SpA & 212 & 1 \\
\hline Telefonica. S.A. & 30 & 1 \\
\hline Tiscali SpA & 35 & 1 \\
\hline Vetrya SpA & 0 & 0 \\
\hline TOTAL ITALLAN SAMPLE & 1.869 & \\
\hline
\end{tabular}

\begin{tabular}{|c|c|c|}
\hline \multirow{2}{*}{$\begin{array}{l}\text { NAME OF SPANISH TELECOMMUNICATIONS } \\
\text { COMPANIES }\end{array}$} & \multicolumn{2}{|c|}{$\begin{array}{l}\text { The number of words dedicate to the futur impact of IFRS } \\
15 \text { in each paragraph that discuss about it }\end{array}$} \\
\hline & N. of words & N. of paragraphs \\
\hline America Movil. S.A.B. & 583 & 1 \\
\hline Cellnex Telecom. S.A & $\mathbf{0}$ & $\mathbf{0}$ \\
\hline Euskal Tel. S.A. & 187 & 1 \\
\hline Global Dominion Access. S.A. & $\mathbf{0}$ & $\mathbf{0}$ \\
\hline Grupo Ezentis. S.A. & 27 & 1 \\
\hline Masmovil Ibercom. S.A. & 121 & 1 \\
\hline TOTAL SPANISH SAMPLE & 918 & \\
\hline PERCENTAGE ON THE TOTAL SAMPLE & 2.787 & \\
\hline
\end{tabular}

\section{Copyrights}

Copyright for this article is retained by the author(s), with first publication rights granted to the journal.

This is an open-access article distributed under the terms and conditions of the Creative Commons Attribution license (http://creativecommons.org/licenses/by/4.0/). 